\title{
Soft sediment deformation structures in the Late Quaternary sediments of Ladakh: evidence of multiple phases of palaeoearthquakes in the North western Himalayan Region
}

\author{
Binita Phartiyal and Anupam Sharma \\ Birbal Sahni Institute of Palaeobotany, 53-University Road, Lucknow-226007, UP, INDIA
}

Ladakh, situated in the tectonically active terrain, in the vicinity of the Indus Suture Zone (ISZ), Shyok Suture Zone (SSZ) and Karakoram Fault (KF), is rich in Quaternary deposits and is truly a treasure trove for Quaternary researchers. This work presents the palaeoseismic signatures as recorded in the Quaternary sediments of the Spituk-Leh (along ISZ) and the Khalsar palaeolakes (along SSZ and KF). These two palaeolakes were a result of a regional tectonic activity at 35,000-40,000 yrs BP. 9 levels of soft-sediment deformation structures (seismites) are recorded from a $>27 \mathrm{~m}$ thick, clay, sand sequence of the Spituk-Leh palaeolake. The deformation levels are confined to the lower $13 \mathrm{~m}$ of the sequence $(0.5,2.7,3.2,3.6,5.5,8.1,9.8$, 12.2 and $13.1 \mathrm{~m})$. The upper part of the paleolakes seems to have stable tectonic conditions. About $90 \mathrm{~km}$ north of this section and separated by the Ladakh batholith, in the $\sim 11 \mathrm{~m}$ thick section of Khalsar palaeolake shows 8 levels of soft-sediment deformation structures at 1.2, 1.5, 4.2, 4.5, 5.4, 8.8, 9.2 and 10.8 $\mathrm{m}$ levels. Deformation sediments are composed of alternations of clay, silts and sand and are restricted to single stratigraphic layers bounded by undeformed beds suggesting synsedimentary deformation. They are simple and complex convolutes, pinch and swell bedding, microfolds and microfaults, flame-like structures, pseudonodules or cycloids, clay diapirs, ball and pillow structures, pillar structures, sedimentary dykes, mud lenses, etc. Lying in the vicinity of the active faults the ISZ, SSZ and $\mathrm{KF}$, these two palaeolake systems record multiple phases of seismic tremors of magnitude $>5$ due to release of stress along these fault systems during the late Quaternary times. 